Published on Reviews in History (https://reviews.history.ac.uk)

\title{
The Slave's Cause: A History of Abolition
}

Review Number: 1991

Publish date: Thursday, 15 September, 2016

Author: Manisha Sinha

ISBN: 9780300181371

Date of Publication: 2016

Price: $£ 22.50$

Pages: 784pp.

Publisher: Yale University Press

Publisher url: http://yalebooks.co.uk/display.asp?K=9780300181371\&nat=false\&sort=\%24rank\&sf1=keyword\&st

Place of Publication: New Haven, CT

Reviewer: Beverly Tomek

Given the volume of recent works produced on the anti-slavery movement of the 19th-century Atlantic world, it was time for someone to create a new synthesis. Manisha Sinha's The Slave's Cause is a synthetic work that traces the long trajectory of the anti-slavery movement in the United States and places it into an international context. It provides a catalogue of antislavery figures, organizations, and publications and will likely serve as a valuable go-to reference work for years to come. Besides bringing the different waves of anti-slavery together in one place, Sinha offers her own conclusions about the anti-slavery movement, primarily that divisions of race, gender, class, and ideology were not as pronounced in the movement as some historians have made them out to be and that the overall history of the movement was one of continuity more than change. Just as importantly, in illustrating the radical nature of the movement she highlights the connection between anti-slavery sentiment and an early critique of capitalism and imperialism.

Rather than seeing the movement as being broken into a series of periods that replaced each other with new ideas and tactics (though she does describe different 'waves' of abolition), Sinha focuses on continuity more than change. She describes the movement was an organic and dynamic one in which activists from one generation to the next considered the same questions and held similar tactical debates. This continuity has become increasingly obvious in the studies produced over the past decade, and Sinha builds upon a host of primary and secondary sources to show readers that, while scholars may continue to divide the movement in broad periods, the issues of each of those periods blended from one into another as the movement advanced.

One of the main continuities of the anti-slavery movement was its interracial nature. Sinha begins her story in Africa, maintaining that, while there is plenty of literature on African participation in the slave trade, scholars often overlook African opposition to the slave trade and to slavery. She points out that the first antislavery writing was produced in West Africa and that the story of the rise of abolition was an interracial one from the beginning. Indeed, she concludes that 'writers of African descent were among the first to wrestle with the problems of race and slavery in the modern West' (p. 9) and that their early works discredited 'the racist logic that dehumanized Africans as slave property' (p. 26). Not only did Africans provide the first written protests, they also led rebellions that went hand in hand with protests by Quakers and other whites in North America. Just as importantly, slaves protested their condition by running away, and their actions influenced white abolitionists like Granville Sharp and led to the famous anti-slavery ruling in the Somerset 
case as well as Dunmore's Proclamation during the American Revolution. Black uprisings, particularly the Haitian Revolution, showcased black abilities and emboldened American blacks. According to Sinha, 'black resistance to slavery was the essential precondition to the rise of abolition' (p. 10).

In the northern states, which saw gradual emancipation in the years immediately following the American War of Independence, slaves and white abolitionists oversaw the process and fought to prevent abuse and backsliding (p. 66). While some historians have cited economic reasons for northern emancipation, Sinha maintains that 'abolitionist mobilization and the desire of blacks for freedom' served as 'the dominant forces behind revolutionary emancipation' (p. 66). She shares the stories of slaves in New England who used their judicial and civil rights to initiate and enforce emancipation, showing that of 28 freedom suits in Massachusetts during the colonial and revolutionary period, only one was unsuccessful (p. 67). Vermont blacks forced state leaders to ban slavery in what became the state constitution and blacks in Massachusetts demanded citizenship as well as freedom. In Pennsylvania, the fate of an enslaved woman named Dinah Nevil encouraged the formation of the Pennsylvania Abolition Society, one of the oldest and most revered antislavery organizations in the world, and blacks pushed for the adoption of the state's emancipation law. After the American Revolution, blacks throughout the northern and middle states 'hastened the process of gradual emancipation by running away, striking deals with their masters, and launching legal challenges' (p. 74). For Sinha, northern emancipation was a case of 'self-purchase by enslaved African Americans writ large' (p. 85) and 'northern emancipation and upper south manumissions had been achieved not through the unfolding of some inexorable revolutionary logic but through ongoing contestations between slaveholders' power and legal prerogatives and enslaved black people and their abolitionist allies' (p. 96).

After emancipation, Sinha maintains, blacks and whites continued to work together for racial equality in the North and abolition in the South. She takes on other historian's criticism of the paternalism of white emancipationists such as those in the Pennsylvania Abolition Society by arguing that 'abolitionist paternalism could be grating for a newly free people, but it could also offer invaluable assistance in securing freedom in education, and in confronting the abuses of northern emancipation laws' (p. 97). She also adds that 'abolitionist notions of racial uplift were tied to a commitment to civic equality' and maintains that even if paternalistic, abolitionist advice and assistance 'was nonetheless invaluable to a newly freed people,' making blacks model citizens and aiding the cause of abolition (p. 113). She also points to the importance of the joint efforts between black Americans and abolitionists who worked through the courts to help blacks gain freedom and education. While some historians have seen blacks as 'objects of white benevolence' during this period, blacks and whites saw each other as 'worthy allies,' with connections to the black community shaping abolitionist society activities (p. 121).

Sinha describes the black community of the United States as an autonomous civil society that developed and grew independently of state sanction or interference. Excluded from the white community and white institutions, blacks built their own. The self-help societies they created provided a bedrock for this parallel society and laid the foundation for abolition efforts. While Prince Hall and several other black leaders have not, as she claims, been neglected by historians, some figures she features, like Scipio Dalton, George Thatcher, and Jacob Oson will be new to many readers (pp. 134, 135, 140, 156). An important arena for black leadership, according to Sinha, was in the South, where it went underground and was kept alive by slave rebels and fugitives who cultivated alliances with free blacks and a few whites (p. 144). It was this arena of the black struggle and the work of blacks in the South that ultimately turned the American Civil War into a war for freedom.

Another continuity Sinha traces is the radical nature of the movement. Countering the traditional argument that the movement radicalized as time wore on, she contends that it was a radical movement all along, particularly when considered through the experiences of black abolitionists. She argues that the black freedom petitions of the Revolutionary Era called for reparations in addition to freedom and adds that black institutional independence encouraged early black abolitionists to create 'a radical antislavery rhetoric that would flower in the antebellum interracial abolition movement' (p. 144). Further, she makes the point that some abolitionists in the first wave, often described by historians as more conservative than those of the 
antebellum period, were more revolutionary than they have been portrayed, suggesting that early abolitionists be viewed through the eyes of those they tried to help rather than the teleological lens of today. She also points out that the demands of the American Convention of Abolition Societies were very similar to those of immediate abolitionists. They featured the desire to stop the expansion of slavery and the hope of putting an end to the domestic slave trade, but they also included a call for general emancipation and for abolition in the South (p. 111).

One of the most interesting points Sinha makes to illustrate the radical nature of abolition involves the way it opened the door for some to critique capitalism and conspicuous consumption. After describing this connection, Sinha traces an anti-capitalist strain in anti-slavery into the Revolutionary period and argues that, in their quest to end the slave trade, black abolitionists in the early 1800s 'fashioned a radical critique of slavery and early capitalism' (p. 151). Quakers like Elias Hicks added to this critique by condemning 'not just slavery but all wealth making and market society' (p. 171). Abolitionist ideology, she explains, 'exposed northern complicity in upholding slavery, connected the sufferings of slaves to national wealth, and developed a discourse of human rights' (p. 246). Their critique of capitalism led to a 'radical internationalism' that 'linked the emancipation of the slaves with that of all laboring people' (p. 339). This focus on the critiques of capitalism goes well with recent works on the connection between slavery and capitalism, most notably Edward Baptist's The Half Has Never Been Told.

Sinha extends her consideration of capitalism and class consciousness into her description of the grassroots nature of the movement. She contends throughout the book that, despite claims by some historians in the past, abolition was not a middle-class movement but instead drew support from all classes. In one of her most innovative points, she cites $\mathrm{X}$ signatures to develop her claim that early black abolitionism was a community-wide movement that bridged class boundaries (p. 140).

According to Sinha, abolition also led reformers to criticize imperialism. In Great Britain, this meant reformers taking their fight against the slave trade into international foreign policy. Similarly, in the United States during the Early Republic years, abolitionists created images and wrote pamphlets that 'transformed the African slave trade from a cog in the imperial machine to an exemplary instance of cruelty and inhumanity' (p. 99).

Finally, Sinha develops her point about continuity to transcend the traditional barriers between political and social history. For Sinha, the movement did not take a political turn in the 1840s but had a political element all along as abolitionists fought to overthrow the slave power and force the United States to live up to the promise of freedom and equality made by the revolutionary generation. This job began as soon as the Constitution was ratified and Sinha describes the role of Federalists in laying the groundwork for political arguments that would later be employed by Whigs and Republicans in their political fight against slavery. She cites Federalist concerns over what would later be labeled 'Slave Power', tracing their argument that 'slaveholders, not slaves, constituted the gravest threat to the Republic' (p. 109). She traces the debate over the relationship between slavery and the Constitution to Absalom Jones, who considered and discussed the issue well before the rise of political abolitionism. She describes the relationship between abolition and politics throughout the Early Republic and Antebellum years, revealing that abolitionists found the most success when they allied with politicians, primarily through the Free Soil movement - a movement which, she maintains, grew out of abolition and then brought anti-slavery into mainstream discourse.

Further, Sinha shows that William Lloyd Garrison did not resist involvement with politics to the extent that some historians have assumed. One of the most interesting aspects of the book is her discussion of Garrison's relationship with politics and political anti-slavery, as she makes a compelling argument that his ideas must be placed within the overall context of political anti-slavery and considered through his engagement with that movement.

Sinha also places the story of abolition within the broader context of the movement for racial equality. She maintains that Richard Allen 'questioned the criminalization of blackness' during the early years of the 
nation's founding (p. 150) and that abolitionists like Theodore Dwight Weld pioneered civil disobedience tactics that would later be borrowed by civil rights activists in the mid-1900s (p. 239). She concludes that the failure to do away with racial barriers and ensure equality for all in the United States was not the fault of abolitionists. She argues throughout the book that abolitionists developed effective tactics and were willing to adapt, make alliances, and be creative when necessary. She adds that they pioneered in the development of modern concepts of human rights. Unfortunately, however, those who opposed equality won many battles and the overall war is still being fought. Even so, 'the history of abolition is an ideal test case of how radical social movements generate energies of political change' (p. 4).

The Slave's Cause is valuable for a number of reasons. Primarily, it offers both the general reader and the specialist a literal catalogue of anti-slavery activists and their major writings - a basic who's who of the movement from the colonial period to the Reconstruction Era. For this reason alone it will long serve as an important reference tool. Secondly, it restores abolitionists' reputations as radicals who dared to fight the prevailing system, even if some of their tactics and conclusions collided not just with the mainstream worldview of the time but also with the ideas of other reformers. Indeed, Sinha's third major contribution lies in showing how, though the focus, tactics, and priorities varied between activists, even at times between those of the same anti-slavery groups, there was more continuity than change over the long term.

In places, however, Sinha tailors her writing to specialists, offering information that a lay reader might not understand. For one matter, she engages in historiographical arguments without directly addressing the secondary source, creating a situation where it is clear that she is arguing with another interpretation but unclear which interpretation she is refuting. (For one example, see footnote seven on p. 14.) Similarly, she sometimes assumes too much prior knowledge of her readers. For example, on p. 16 she says paternalism 'was not yet yoked to proslavery dogma' but a general reader would not know what that statement means. Also, she compares Anthony Benezet to William Lloyd Garrison well before there is any discussion of Garrison (p. 20). Of course, these examples would not bother other abolition historians, or perhaps other historians in general, but as in most places the book feels like it is meant for general readers or newcomers to the field this leaves an occasional sense of confused purpose.

One other issue lies in Sinha's use of straw man arguments that interrupt her narrative and detract from the importance of the synthetic nature of her story. One of the most obvious examples lies in her referring to the first wave of abolition as 'largely forgotten' and her assertion that it is 'commonly assumed' that American abolition waned after the Revolution (p. 97). Further, she claims that African Americans' struggle for the vote and against segregation and racial violence 'is often forgotten in the history of abolition' (p. 299). This has not been the case for a while now, as many historians have worked over the past few decades not only to bring more light onto this period but also to connect it to the later abolition and civil rights movements. Sinha's footnotes show an awareness of many of these works. Similarly, though she wants to rescue black figures and their stories from oblivion, she is a generation too late, as historians have already rescued most of them. There is still important work to be done to expand on their stories, but there is no need to ignore the body of research and literature that already exists. Throughout the book Sinha cites secondary works of relevance in the footnotes, even after claiming neglect in the text. The book provides a nice synthesis that would be even better without this type of argument and these attempts to claim originality. It would have been better had she engaged the secondary literature clearly and directly in the text rather than putting herself in the strange position of using the work of other historians while discounting their existence.

\section{Other reviews:}

Times Higher Education

https://www.timeshighereducation.com/books/review-the-slaves-cause-a-history-of-abolition-manisha-sinhayale-university-press [2]

New York Times

http://www.nytimes.com/2016/02/28/books/review/the-slaves-cause-a-history-of-abolition-by-manishasinha.html [3]

The Atlantic http://www.theatlantic.com/magazine/archive/2016/04/the-truth-about-abolition/471483/ [4] 
H-Net

https://networks.h-net.org/node/2606/discussions/109745/slave\%E2\%80\%99s-cause-history-abolition-bookdiscussion-author-manisha [5]

Kirkus

https://www.kirkusreviews.com/book-reviews/manisha-sinha/the-slaves-cause/ [6]

Source URL:https://reviews.history.ac.uk/review/1991

\section{Links}

[1] https://reviews.history.ac.uk/item/171254 [2] https://www.timeshighereducation.com/books/review-theslaves-cause-a-history-of-abolition-manisha-sinha-yale-university-press

[3] http://www.nytimes.com/2016/02/28/books/review/the-slaves-cause-a-history-of-abolition-by-manishasinha.html?_r=0 [4] http://www.theatlantic.com/magazine/archive/2016/04/the-truth-about-abolition/471483/ [5] https://networks.h-net.org/node/2606/discussions/109745/slave\%E2\%80\%99s-cause-history-abolitionbook-discussion-author-manisha [6] https://www.kirkusreviews.com/book-reviews/manisha-sinha/the-slavescause/ 